\title{
Motivation of Poor Household Women In Productive Economic Enterprises Based on Personal Factors
}

\author{
Suminah \\ Faculty of Agriculture \\ Universitas Sebelas Maret \\ Surakarta, Indonesia \\ sum_anan@yahoo.com \\ Mei Tri Sundari \\ Faculty of Agriculture \\ Universitas Sebelas Maret \\ Surakarta, Indonesia \\ meitri_sundari@yahoo.com
}

\author{
Arip Wijiyanto \\ Faculty of Agriculture \\ Universitas Sebelas Maret \\ Surakarta, Indonesia \\ aripkoe@yahoo.com \\ Mujiyo \\ Faculty of Agriculture \\ Universitas Sebelas Maret \\ Surakarta, Indonesia \\ mujiyo@staff.uns.ac.id
}

\begin{abstract}
Women's empowerment programs for poverty alleviation have been carried out by government, but the results are still nonptimal yet. The problem of poverty becomes more complicated, because in fact women's poverty is not only caused by limited access to economic resources, but also because of their own personality as factors. This study aims to analyze the influence of personal factors (attitudes, cosmopolitanity, locus of control, and adversity quotient) on women's motivation in productive economic enterprises. Quantitative method used in this research. The research hypothesis assume that personal factors (attitudes, cosmopolitanity, locus of control, and adversity quotient) of poor households has influence toward their motivation in running productive economic enterprises. I'm this research, to analyze the motivation of women in productive economic enterprises involving 210 women of poor households as a sample. The results of the analysis showed that personal factors, cosmopolitan and adversity quotient have a positive effect on motivation, while the locus of control does not affect the motivation of poor women in productive economic enterprises.
\end{abstract}

Keywords-Attitude, Adversity quotient,
Cosmopolitan motivation

\section{INTRODUCTION}

Poverty is a social phenomenon which is characterized by the inability of a person or group to meet the standards of basic daily needs, or it can be said to be unable to obtain a minimum standard of living. In the province of Central Java, the percentage of poor people in September 2012 reached $14.98 \%$, far greater than the percentage of poor people in Indonesia of $11.66 \%$ [1]. [2] details the poor population being very poor as many as $1,395,572$ people equivalent to 348,893 poor households or Rumah Tangga Miskin (RTM); the poor population of $6,178,052$ people is equivalent to $1,544,513 \mathrm{RTM}$, and the near poor population is $5,111,180$ people, equivalent to $1,277,795 \mathrm{RTM}$.

Efforts to empower poor families in the economic field aim to foster and increase the interests, enthusiasm, and family skills in the productive economy. Some strategies for economic empowerment of poor families aim to increase the creativity and productivity of families through empowerment in the business field and skills with the main activities such as growth and development of groups. Where the whole series of family economic empowerment activities are carried out through a group approach, including through business groups to increase family income or "Usaha Peningkatan Pendapatan Keluarga Sejahtera" (UPPKS). Guidance and group business development activities are carried out through improving human resources, partnership development, business network continuity, production development, and capital development, as well as empowerment in accessing the market.

With regard to poverty, women's empowerment programs are one of the programs that are expected to contribute to overcoming poverty. One of the policy approaches related to the position of women in development is the empowerment approach. The approach emphasizes the importance of women to improve their empowerment in the sense of having skills and internal strength.

The women's empowerment program in an effort to improve the economy of poor families is expected to increase the income of poor households, which is then abbreviated as RTM women through the formation of joint business groups that have been facilitated by the government and non-government. The number of empowerment programs for RTM women in the economic field, the reality is not necessarily followed by an increase in their empowerment in productive economic enterprises, especially in the field of food. It can be seen that, although this empowerment effort has been carried out for three decades, through training to increase knowledge and skills, facilitation of both physical facilities, equipment, and capital provision, the conditions are still not optimal. The Prosperous Family Income Improvement Business Group (UPPKS) in Solo Raya which included Wonogiri, Sukoharjo, Karanganyar, Sragen, Boyolali, Klaten and Surakarta cities showed that there were 9,752 groups consisting of: 7,672 basic category groups; 3,286 categories of developing groups, 940 categories of independent categories [3]. 
This condition is inseparable from the influence of the individual's own factors which provide reinforcement, namely motivation. Work motivation is a concept that describes the power that is in a person who starts and directs behavior to work [4]. Motivation directs someone to do a job in accordance with their potential. Motivation can increase individual enthusiasm in carrying out their activities, including empowerment in carrying out productive economic efforts. Motivation is also defined as an urge from within an individual where he tries and behaves in a certain way to fulfill his wants or needs [4]. Needs are everything that if not fulfilled will result in the emergence of physiological and psychological imbalances. These needs are realized and some are not realized [5]. Alderfer's differentiates human needs into three needs. He argues that needs can be simplified into 3 categories (sets) of needs, namely: (1) existence (needs), the need to maintain one's existence in his life. These needs will be satisfied by factors such as food, air, water, salary and working conditions. The need to continue to exist is a simplification of physiological needs and security in Maslow's theory; (2) relatedness needs, the need to interact with other people, who are satisfied with meaningful social and interpersonal relationships. This need is identical to social needs and selfesteem in Maslow's theory; (3) growth needs, the needs of self-development are satisfied by creating creative and productive contributions. ERG theory states that motivated individuals behave to satisfy one of the 3 groups of needs. Alderfer emphasizes that these three needs are not hierarchically arranged [4]

Encouragement is a factor that strengthens or directs one's efforts and behavior. If the driving factor is very strong then it will form a hard effort to achieve it. Encouragement as a motivational keyword can arise as a result of a desire to meet an insatiable need or internal drive.

The results of the study by [6] state that there is a significant positive relationship between personal factors and empowerment. Personal factors also have an influence on motivation. Motivation and personality also have a positive relationship with goal setting. With regard to personality, people with good personalities will satisfy psychological needs creatively and productively, while people with poor personalities satisfy needs in an irrational way Fromm (1968) in (Burger, 2000) [7].

Personality factors such as attitudes, cosmopolitan, innovativeness, effort and perseverance also influence motivation [8]. A person's motivation is influenced by personality factors such as choosing behavior, effort, perseverance, and adversity quotient, mindset and emotional reactions. In connection with locus of control (control center) shows that locus of control is one of the personality variables (personality), which is defined as individual confidence in the ability to control fate (destiny) itself [9].

Based on the description above, this study seeks to obtain a more definite picture to answer whether the motivation of female RTM in productive economic enterprises is influenced by personal factors such as attitudes, cosmopolitanism, adversity quotient and locus of control. These variables are important, because the empowerment of RTM women is not solely a matter of capital and technical skills, but also the problem of how to generate self-motivation to carry out productive economic efforts to meet the needs of life. However, in reality there have been no studies that have examined the motivation of RTM women in carrying out productive economic ventures in the food industry. Although there have been many complaints from empowerment officers regarding the inaction of RTM women in undertaking productive economic activities in the type of food business.

The aforementioned phenomenon is very important to examine how much personal factors contribute to the motivation of RTM women to undertake productive economic ventures, the results of which are expected to be used as a basis for formulating a model for empowering RTM women in productive economic ventures, especially food businesses in Solo Raya.

\section{METHODS}

This research is explanatory research, which interacts in social interaction phenomenon in the community. The population in this study were all poor household women who had productive economic businesses in Solo Raya. The method used was quantitative method with survey techniques, and to ensure the accuracy of quantitative results, qualitative information should include them to get better understanding of the concepts under study. The samples were taken by a couple of random sampling, and selected 210 of poor women in productive economic activities.

Primary data which includes attitudes, cosmopolitan, adversity quotient, locus of control, and motivation of poor woman in productive economic activities are obtained through interviews using questionnaires and direct observation in the field. Data obtained from these five variables are in the form of an ordinal score, then processed first into an interval scale, using a Likert model scale so that it can be processed with parametric statistics [10]. The data that has been Likert is then analyzed for its validity and reliability by using Cronbach Alpha, with the criteria if the Cronbach Alpha coefficient is greater than 0.70 it is said to be reliable [11] [12], Appendix Table 1. In this study, measuring instruments using a scale, which is oriented to the subject as Torgeson points out [13].

Table 1. The Results of the Reliability of the Research Instrument

\begin{tabular}{cccl}
\hline Variable & $\begin{array}{c}\text { Cronbach's } \\
\text { Alpha }\end{array}$ & $\begin{array}{c}\text { Limitati } \\
\text { on Score }\end{array}$ & Interpretation \\
\hline Motivation & 0.813 & 0.70 & Reliable \\
\hline Attitude & 0.876 & 0.70 & Reliable \\
\hline Cosmopolitanity & 0.879 & 0.70 & Reliable \\
\hline $\begin{array}{c}\text { Adversity } \\
\text { Quotient }\end{array}$ & 0.901 & 0.70 & Reliable \\
\hline $\begin{array}{c}\text { Locus of } \\
\text { Control }\end{array}$ & 0.910 & 0.70 & Reliable \\
\hline & Source: Primary Data Analysis, 2015
\end{tabular}

To describe the research variables, each variable is categorized into three categories based on interval scale, namely low, medium, and high categories. Prior to categorization, the class interval is determined based on the item score by using categorization based on the normal distribution model [13]. To give meaning to the level of achievement in percentage form refers to the percentage level as follows: 
Percentage level $\quad 0 \% \quad 20 \% \quad 40 \% \quad 60 \% \quad 80 \% \quad 100 \%$

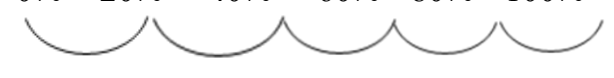

$\begin{array}{llllll}\text { Interval score } & 0 & 1 & 2 & 3 & 4\end{array}$

Next to test the hypothesis of this study used multiple regression statistical tests.

\section{RESULTS AND DISCUSSION}

\section{A. Descriptive Analysis of Achievement Level of Each Research Variable}

The percentage of motivation, attitude, cosmopolitan, locus of control, and adversity quotient level categories shows that the majority of poor households in carrying out productive economic businesses in the food sector in Solo Raya have a $100 \%$ motivation included in the high category, their attitudes are also included in high category that is equal to $100 \%$, cosmopolitan $48.6 \%$ included in the medium category, $100 \%$ adversity quotient is included in the high category, as well as $100 \%$ locus of control included in the high category, the results of calculations are presented in Table 2. These results provide information that the motivation and personal factors of women in poor households in Solo Raya in carrying out productive economic businesses show a sufficient level, meaning that they have a strong drive to be able to run a productive economic business.

Table 2. Distribution of Achievement Level of Each Research Variable

\begin{tabular}{|c|c|c|c|c|c|c|c|c|}
\hline \multirow{3}{*}{ Variable } & \multicolumn{6}{|c|}{ Category } & \multirow{2}{*}{\multicolumn{2}{|c|}{ Total }} \\
\hline & \multicolumn{2}{|c|}{ Low } & \multicolumn{2}{|c|}{ Medium } & \multicolumn{2}{|c|}{ High } & & \\
\hline & $\mathrm{N}$ & $\%$ & $\mathrm{~N}$ & $\%$ & $\mathrm{n}$ & $\%$ & $\mathrm{n}$ & $\%$ \\
\hline Motivation & 0 & 0.0 & 0 & 0.0 & 210 & $\begin{array}{r}100 . \\
0 \\
\end{array}$ & 210 & $\begin{array}{r}100 \\
.0 \\
\end{array}$ \\
\hline Attitude & 0 & 0.0 & 0 & 0.0 & 210 & $\begin{array}{r}100 . \\
0\end{array}$ & 210 & $\begin{array}{r}100 \\
.0 \\
\end{array}$ \\
\hline $\begin{array}{c}\text { Cosmopolita } \\
\text { nity }\end{array}$ & 85 & 40.5 & 102 & $\begin{array}{r}48 . \\
6 \\
\end{array}$ & 23 & 11.0 & 210 & $\begin{array}{r}100 \\
.0 \\
\end{array}$ \\
\hline $\begin{array}{c}\text { Adversity } \\
\text { Quotient }\end{array}$ & 0 & 0.0 & 0 & 0.0 & 210 & $\begin{array}{r}100 . \\
0 \\
\end{array}$ & 210 & $\begin{array}{r}100 \\
.0 \\
\end{array}$ \\
\hline $\begin{array}{c}\text { Locus of } \\
\text { control }\end{array}$ & 0 & 0.0 & 0 & 0.0 & 210 & $\begin{array}{r}100 . \\
0\end{array}$ & 210 & $\begin{array}{r}100 \\
.0\end{array}$ \\
\hline
\end{tabular}

The high level of achievement of motivation is due to wanting to be able to meet the needs related to the business being carried out. These motivations include motivation to get additional business capital, want to improve production and marketing processes, want to make books, and want to partner with other parties. In addition they also want to be considered by others, want to develop new innovation products in the business that they are running. This means they also want to be rewarded for everything they do.

The attitude of women RTM in carrying out productive economic businesses is also included in the high category. This means that RTM women have a good attitude towards the business being carried out, starting from capital, production processes, marketing, bookkeeping and partnership.

Cosmopolitan is the level of openness of RTM women who are oriented outside the social system with broad interpersonal relationships. The level of cosmopolitan achievement of RTM women is in the medium category which means that not all RTM women have ever traveled outside their regions to access information on business management technology, to the market looking for information on prices such as raw materials, product selling prices, production processes and packaging needed, as well as information competition for other similar businesses.

The locus of control of RTM women on productive economic enterprises is the trust of poor women in their ability to control their own destiny in relation to the productive economic activities carried out. Measurement of locus of control variables using an instrument developed by [14] which is divided into internal and external locus of control. Locus of control of RTM women in carrying out productive economic businesses is included in the high category. This means that the views of RTM women on the ability to determine their own destiny in carrying out a productive economic business are good. Likewise, the views of RTM women on outside sources that control the events of their lives, such as fate, fortune, power of the leader, and the surrounding environment are also good. The adversity quotient of RTM women towards productive economic enterprises is included in the high category. This can be explained that RTM women have a high adversity quotient in overcoming difficulties faced by productive economic enterprises.

\section{B. Descriptive Analysis of Characteristics of Women's Productive Economic Business RTM}

\section{1) Type of business}

The type of business carried out by female RTM is actually very diverse, according to which the business program of increasing family income includes the fields of agriculture, livestock, home industry, services, trade and savings and loans. In this study only limited to the food business sector. The results of the study can be seen in Table 3.

Table 3. Types of Food Businesses Run by Women RTM

\begin{tabular}{llcc}
\hline No. & \multicolumn{1}{c}{ Types Business } & $\begin{array}{c}\text { Amount } \\
\text { (Person) }\end{array}$ & $\begin{array}{c}\text { Precentage } \\
(\%)\end{array}$ \\
\hline 1. & Making tofu & 10 & 4.67 \\
2. & Rambak, crackers, slabs & 18 & 8.67 \\
3. & Various ice cream, mixed, & & \\
& fruit & 7 & 3.33 \\
4. & Marning & 7 & 3.33 \\
5. & Tempe, kripik tempe & 42 & 19.33 \\
6. & Various breads, and market & & \\
& snacks, keleman & 38 & 18.00 \\
7. & Fried noodles, boiled & 11 & 5.33 \\
8. & Various fried foods & 8 & 4.00 \\
9. & Fried chicken, chicken & & \\
$\quad$ satay & 11 & 5.33 \\
10. & Snack squid and stick & 1 & 0.67 \\
11. & Jamu & 17 & 8.0 \\
12. & Vegetable rice, various side & & \\
$\quad$ dishes & 22 & 10.67 \\
13. & Making gaplek & 1 & 0.67 \\
14. & Onde-onde & 4 & 2.00 \\
15. & Cilok, grilled meatball & 13 & 6.00 \\
\hline & Total & 210 & 100.00 \\
\hline
\end{tabular}

Source: Primary Data Analysis, 2015

The type of business carried out varies according to the abilities, skills and interests of poor women in business. Most of the $19.33 \%$ of poor household women have productive economic businesses such as making tempeh 
and chips. Making a variety of breads, market snacks, and keleman ranks second at $18.0 \%$, an effort to make cilok and grilled meatballs by $14.0 \%$, vegetable business and various side dishes by $10.67 \%$, and the rest of the type of business occupied includes making rambak crackers, cilok, making tofu, crackers, marning, dumplings and various ice cream, fruit ice.

The efforts made by these poor female households, the majority of which are based on the skills possessed from their parents for generations. They do not work in other sectors because of the limitations of education, experience and skills, so that employment opportunities in other sectors are difficult to obtain. In addition, the reason why they prefer to pursue productive economic business fields is because in general they can overcome unemployment to meet the needs of their families.

\section{2) Capital}

Productive economic undertakings carried out by RTM women, generally in the form of businesses managed by someone themselves by employing household members. The category of business is generally classified as a family business (family enterprise, family business), because one of them carries the risk (responsible for management) which in this study women are responsible. With regard to the capital used by poor women to undertake productive economic enterprises, it is explained in Table 4.

Table 4. Types of Capital Resources

\begin{tabular}{clcc}
\hline No. & \multicolumn{1}{c}{$\begin{array}{c}\text { Types of Capital } \\
\text { Resources }\end{array}$} & $\begin{array}{c}\text { Amount } \\
\text { (Person) }\end{array}$ & $\begin{array}{c}\text { Percentage } \\
(\%)\end{array}$ \\
\hline 1. & Bank & 24 & 11.53 \\
2. & Cooperative & 43 & 20.30 \\
3. & Family & 21 & 10.23 \\
4. & Neighbor & 10 & 4.93 \\
5. & Not borrow & 46 & 22.00 \\
6. & Friend & 18 & 8.53 \\
7. & PKK(savings and loan) & 15 & 6.90 \\
8. & PNPM/P2KP & 17 & 8.17 \\
9. & Groups & 16 & 7.40 \\
\hline \multicolumn{2}{c}{ Total } & 210 & 100.00 \\
\hline \multicolumn{2}{c}{ Source: Primary Data Analysis, 2015}
\end{tabular}

In carrying out productive economic businesses for women, poor households are very dependent on the existence of venture capital. So far, poor women in Solo Raya, related to business capital, mostly $22.0 \%$ do not make loans with a variety of reasons, such as fear of not being able to pay, feel they are sufficient with the current conditions (as they are) do not want to neka, don't want a lot of business. There are also RTM women who do not borrow business capital because some of them already have business capital provided by their children who migrate in the city, or become TKI / TKW. The smallest percentage is borrowing neighbors, which is $4.93 \%$.

\section{3) Quantitative Analysis}

Quantitative analysis is used to test the research hypothesis, using multiple regression [12]. Multiple regression analysis is used to determine the effect of independent variables on the dependent variable. Based on regression analysis, the results obtained as presented in Table 5 are obtained. From the results of regression analysis as shown in Table 5, the regression equation model can be arranged as follows: $\mathrm{Y}=84,287+0,721 \mathrm{Skp}+0,615$ Kosplt $+0,198$ LoC $+0,438$ DJ

Table 5. Results of Analysis of Personal Variables to Motivation

\begin{tabular}{lrrrr}
\hline Variable & $\begin{array}{c}\text { B } \\
\text { (Beta) }\end{array}$ & $\begin{array}{c}\text { Coefficient } \\
\text { Regression }\end{array}$ & t-count & Significant \\
\hline Constanta & & 84.287 & 6.755 & $0.000^{* * *}$ \\
\hline Attitude & 0.193 & 0.721 & 2.931 & $0.004^{* *}$ \\
\hline Cosmopolitan & 0.376 & 0.615 & 5.886 & $0.000^{* *}$ \\
\hline $\begin{array}{l}\text { Locus of } \\
\text { control }\end{array}$ & 0.122 & 0.198 & 1.496 & $0.136^{\mathrm{NS}}$ \\
\hline $\begin{array}{l}\text { Adversity } \\
\text { Quotient }\end{array}$ & 0.214 & 0.438 & 3.075 & $0.002^{* *}$ \\
\hline F-count & 12.828 \\
\hline Adjusted R Square & 0.284 & & 0.000 \\
\hline
\end{tabular}

Source: Primary Data Analysis, 2015 Description: $* *)$ significant at $\alpha=0.05$; NS) non-significant at $\alpha=0.10$

Influence of Personal Variables Together Against Motivation. The influence of personal factors consisting of attitudes, cosmopolitan, locus of control and adversity quotient together on the motivation of female RTM in carrying out productive economic businesses can be known by conducting an $\mathrm{F}$ test. From Table 5 it is known that the significance value is 0.000 smaller from the value of $\alpha=$ 0.05 . This shows that attitudes, cosmopolitanism, locus of control, and adversity quotient together have a significant effect on the motivation of RTM women in carrying out productive economic businesses. The amount of influence of attitude, cosmopolitan, locus of control, and adversity quotient to motivation can be shown from the value of adjusted $R^{2}$. The value of adjusted $R^{2}$ in the table is 0.284 which means that the personal variable affects motivation by $28.4 \%$, while $71.6 \%$ is influenced by other variables outside the model.

\section{4) The Partial Influence of Personal Variable on the} Motivation

Based on the results of the analysis, it is known that the significant value of attitude was 0.004 which is smaller than the value of $\alpha=0.05$. It means that the attitude has a significant effect on motivation at the level of significance is up to $95 \%$. The coefficient value of attitude regression is 0.721 which indicates that the attitude is positively related to motivation. It means that each increase in one unit of RTM women's attitude can increase the motivation to work on an enterprise of 0.721 . One of the adoption strategies that can be done by a change agent is to develop a positive general attitude towards change to the half number of the clients [15]. It is relevant to the results of [16] which states that there is a strong influence between attitudes and motivation on entrepreneurship interest.

The significant value of cosmopolitan is 0.000 which is smaller than the value of $\alpha=0.05$. It means that the cosmopolitan has a significant effect on motivation at the significance level is up to $95 \%$. The coefficient value of cosmopolitan regression is 0.615 which shows that the 
cosmopolitan has a positive effect on motivation. It indicates that each increase in a cosmopolitan unit can increase the motivation by 0.615 .

The analysis of the variables that have the most influence on the RTM women's motivation in carrying out productive economic enterprise can be seen from the beta value or standardized coefficients. Table 5 shows that the cosmopolitan variable has the greatest influence on the RTM women's motivation in carrying out productive economic enterprise with a value of 0.376 . It can be explained that the motivation of RTM women working on productive economic enterprises can be increased if they often leave the social system (the environment in which they are living).

The results of this study are relevant to [15] whose cosmopolitan levels definition are as follows: "Cosmopoliteness is the degree to which an individual is oriented outside a social system." Innovators (pioneers) are the members of a social system but they have the cosmopolitan orientation which often comes out from their social system. This orientation makes the innovators regardless of the obstacles of the local system and makes it possible to have personal freedom in trying new ideas that have never been tried. It is in line with the opinion [17] that the level of cosmopolitan is characterized by the frequency and travel distance that has been done as well as the use of mass media. For those who are relatively cosmopolitan, the adoption of innovation takes place faster. However, for those who are more local (closed in their own social system), the process of adopting innovation takes place more slowly because there are no new desires to live better as what has been experienced by others who come outside their own social systems.

Cosmopolitan is the nature of RTM women who always attempt to get the information that is required to carry out their productive economic enterprises. The indicator is the frequency of visits within and outside the village to find out the information related to their enterprise and have more communication with others as well as make a contact with those coming from outside the enterprise they pursue. According [18] that the farmers who often make a contact or communication with the educators from various activities will increase their knowledge and skills in adopting technology in a better way.

The significant value of locus of control was 0.136 greater than the value of $\alpha=0.05$ which means that the locus of control has no significant effect on motivation at the significance level was up to $95 \%$. The coefficient of locus of control regression was 0.198 which indicates that locus of control cannot affect motivation. It means that the high and low locus of control of RTM women cannot increase their motivation in carrying out productive economic enterprises.

The results of this study do not support the results of [19] study which states that an internal locus of control is positively related to self-efficacy. It is because the individuals having an internal locus of control perceive themselves as having excellent abilities and have high optimism in completing the tasks. In the other words, individuals who have an internal locus of control tend to have high self-efficacy. It contradicts with the study conducted by [20] which states that internal locus of control has no correlation with job satisfaction. The tendency of negative outcome indicates that RTM women in carrying out productive economic enterprises have an external locus of control rather than internal locus of control. Therefore, they have not yet been able to build self-confidence to pursue the achievement. RTM women in carrying out the enterprise tend to be monotonous and less creative in their work. As stated by Kreitner \& Konicki (2009) in [21], individuals who have an internal locus of control tendency are those who have the confidence to be able to control all behaviors and consequences by themselves.

The significant value of the adversity quotient of 0.002 is smaller than the value of $\alpha=0.05$ which means that adversity quotient has a significant influence on motivation at the significance level is up to $95 \%$. The coefficient value of adversity quotient regression is 0.438 which indicates that adversity quotient can affect the motivation by 0.438 . It means that each increase in RTM women's adversity quotient will increase the motivation by 0.438 . It is relevant to the results of the study from [22] stating that there was an effective contribution from the struggle of regulationbased learning in adolescents. The adversity quotient is the ability of the individuals to survive in dealing with and overcoming all difficulties that occur by being resilient and earnest in achieving the desired goals [23]. Adversity quotient is a predictor of one's success in facing the difficulties. It is an individual's attitude who can face and control the difficult situations that occur in their lives. In relation to the adversity quotient of RTM women, they experience difficulties in fulfilling the family needs for almost every day [24]. However, they remain resilient and earnest in overcoming the difficulties that might be experienced. It includes the difficulty in carrying out productive economic enterprises. The biggest difficulty in carrying out productive economic enterprise is about production and bookkeeping technology (because the majority of their education is relatively low).

\section{CONCLUSION}

The personal factors of RTM women having the high level of achievement $(92.4 \%)$ are in the high category. It can be explained that RTM women in carrying out productive economic enterprises are mostly cosmopolitan and have high attitude and power struggle. The motivation of poor women in carrying out a food industry is also included in the high category $(100 \%)$. The motivation arises due to the needs ranging from primary to secondary needs at once. Cosmopolitanism is an important element since it has the greatest influence on the motivation of poor women in carrying out productive economic enterprises. The motivation of poor household women is not always hierarchical as stated in Maslow's theory that the fulfillment of one's needs does not have to start from fulfilling the basic needs which then continued to the higher needs. However, fulfilling one's needs may not be hierarchical which means that someone has a desire to fulfill the need for food as well as the need to feel safe, comfortable, and also want to be appreciated. To increase the motivation of RTM women in carrying out productive economic enterprises, they 
should be brought directly to an enterprise place that is relevant to the enterprise they are engaged in order to learn and observe directly starting from the beginning of the production process to marketing. Thus, the attitude, cosmopolitanity, and adversity quotient can increase which will affect on increasing their motivation in carrying out productive economic enterprises. Therefore, they can have a direct learning experience or learn from observing others who have succeeded in their enterprise. One thing that is not less important for empowering women RTM institutions before conducting an empowerment program is knowing their motivation so that the empowerment program can be effective and efficient.

\section{ACKNOWLEDGMENT}

This article is the part of the top research grant for Sebelas Maret University (UNS). The authors would like to thank Sebelas Maret University for funding this research through BLU funds.

\section{REFERENCES}

[1] BPS, Jawa Tengah Dalam Angka. Semarang: Badan Pusat Statistik Propinsi Jawa Tengah, 2014.

[2] Anonim, Dukungan Propinsi Jawa Tengah Dalam Upaya Penanggulangan Kemiskinan. Semarang: Bappeda Jawa Tengah, 2011

[3] Suminah, Laporan Hasil Evaluasi Kegiatan Sibermas, Surakarta: P3GKM Universitas Sebelas Maret, 2011.

[4] Gibson, J.L., Ivancevich, J.M., dan Donnelly, J.H., 1997, Organizations: Behavior, Structure, Processes, Chicago: IRWIN.

[5] Terry GR, Principles of Management, 8th Edition. Terjemahan Winardi: Asas-Asas Manajemen. Cetakan IV. Bandung: PT. Alumni, 1986.

[6] Lee, M., \& Klein Koh.J., Is Empowerment Really a New Concept, International Journal of Human Resource Management, 12(4), 684695. 2002.

[7] Burger, JM, Personality (5 th ed) Belmont, CA: Wadsworth. 2000.

[8] Bandura, A., Self Efficacy: The Exercise of Control, New York: WH. Freeman and Company. 1996,

[9] Zimmerman B.J., Investigating Self Regulation and Motivation: Historical Bacground, Methodological Developmen, and Future Prospect, American Educational Research Journal 45 (1) pp. 166183, 2008.

[10] Suryabrata, S., Psikologi Kepribadian, Jakarta: CV. Rajawali, 2000.

[11] Nunnaly,J. dan Bernstein, IH., Psychometric Theory, New York, McGraw-Hill, 1994.

[12] Ghozali, I., Aplikasi Analisis Multivariate Dengan Program IBMSPSS 19, Semarang: Universitas Diponegoro, 2011.

[13] Azwar, S., Penyusunan Skala Psikologi, 1- 51. Yogyakarta: Pustaka Pelajar, 2009

[14] Rotter, General Measures Internal Locus of Control Scale, Journal of Psycological Monograph, Vol. 8 (4) pp. 609, 1996.

[15] Rogers, Alan, Education for Development. Cassell Educational Limited: London, 2003.

[16] Ravinder, R., and Narayana, N., Gender Empowerment in Africa: An Analysis of Woman Partisipation in Eritrean Economy, International Journal of Woman, Sosial Justice and Human Rights, 2, pp. 221-237, 2009.

[17] Mardikanto, T., Konsep-konsep Pemberdayaan Masyarakat: Acuan Bagi Aparat Birokrasi, Akademi, Praktisi, dan Peminat/Pemerhati Pemberda-yaan Masyarakat, Surakarta: UNS Press, 2013.

[18] Sudarmaji, 1990, Teknik Fumigasi Tikus Sawah dengan Phostoxin Tablet, Karbit, dan Belerang. Kongres HPTI, 8-10, Februari 1990 Jakarta $8 \mathrm{p}$

[19] Phillips, J. M., \& Gully, S. M., Role of Goal Orientation, Ability, Need for Achievement, and Locus of Control in the Self-efficacy and Goal--setting Process. Journal of Applied Psychology, 82(5), pp. 792-802, 1997.
[20] Hastuti W. \& M. Farid, Motivasi Kerja, Internal Locus of Control \& Kepuasan Kerja Pada Karyawan Bagian Marketing dan Supporting di PT X Cabang Surabaya, Pesona Jurnal Psikologi Indonesia Vol. 4, No. 2, pp. $195-207,2015$.

[21] Singh, K.S. \& Vivek, T., Relationship Between Motivation and Job Satisfaction of the white Collar Employees: A Case Study, Management of Journal, Vol. VII, No. 2, pp. 31-39, 2011.

[22] Herawati, Y. \& Ratna, W., Hubungan antara Keberfungsiaan Keluarga \& Adversity quotient dengan Belajar Berdasarkan Regulasi Diri Pada Remaja, Jurnal Psikologi, Vol. 9, No. 2, 2013.

[23] Stoltz, G.P., Adversity Quotient Turning Obstacles into Opportunities, New York: Jonh Willey \& Sons, 1977.

[24] Phoolka, SE. R. \& Kaur, N., Adversity Quotient: A New Paradigm to Explore, International Journal of Cotemporary Business Studies 3 (4), pp. 68-78, 2012. 